\title{
Therapeutic Approaches in Prion Disease
}

\author{
Naomi S. Hachiya, ${ }^{a, b}$ Yuji Sakasegawa, ${ }^{a, b}$ and Kiyotoshi Kaneko ${ }^{* a, b}$ \\ a Department of Cortical Function Disorders, National Institute of Neuroscience, National Center of Neurology and Psychiatry, 4-1- \\ 1 Ogawahigashi, Kodaira, Tokyo 187-8502, Japan and ${ }^{b}$ Core Research for Evolutional Science and Technology (CREST) of Japan \\ Science and Technology Corporation, 4-1-8 Honcho, Kawaguchi-shi, Saitama 332-0012, Japan
}

(Received April 9, 2003)

\begin{abstract}
Prion protein (PrP) exists in two different isoforms; a normal cellular isoform $\left(\mathrm{PrP}^{\mathrm{C}}\right)$ and an abnormal infectious isoform $\left(\mathrm{PrP}^{\mathrm{Sc}}\right)$, the latter is a causative agent of prion disease such as Bovine Spongiform Encephalopathy (BSE, mad cow disease) and Creutzfeldt-Jakob disease (CJD). Great concern about variant CJD, which is caused by ingesting BSE-contaminated products, is also emerging and spreading over Japan since the first BSE-affected cattle was identified in September, 2001. The amino acid sequences of $\mathrm{PrP}^{\mathrm{C}}$ and $\mathrm{PrP}^{\mathrm{Sc}}$ are identical, but their conformations are rather different; $\operatorname{PrP}^{\mathrm{C}}$ is rich in the non $\beta$-sheet isoform while $\mathrm{PrP}^{\mathrm{Sc}}$ is rich in the $\beta$-sheet isoform. Our prion research focuses on further understanding such an unprecedented mechanism by identifying auxiliary factor(s) other than $\mathrm{PrP}^{\mathrm{C}}$ and $\mathrm{PrP}^{\mathrm{Sc}}$. These studies also help us to develop "therapeutics and prevention methods" for prion disease. Three major trials; genetic manipulation with dominant negative mutant $\operatorname{PrP}^{\mathrm{C}}$ gene working against a hypothetical hostspecific factor, antibody therapy with anti-PrP antibodies which block $\mathrm{PrP}^{\mathrm{C}}-\mathrm{PrP}^{\mathrm{Sc}}$ binding, and $\mathrm{PrP}^{\mathrm{Sc}}$ unfolding therapy with a novel-class molecular chaperone, are currently underway.
\end{abstract}

Key words — prion protein, prion disease, dominant negatives, anti-prion protein antibody, molecular chaperone

\section{Prions and Prion Disease}

Many lines of evidence have argued persuasively that prions are composed largely, if not exclusively, of the scrapie isoform of prion protein (PrP). An abnormally folded isoform ( $\left.\mathrm{PrP}^{\mathrm{Sc}}\right)$ of the normal, cellular prion protein $\left(\operatorname{PrP}^{\mathrm{C}}\right)$ stimulates the conversion of $\operatorname{PrP}^{\mathrm{C}}$ into nascent $\mathrm{PrP}^{\mathrm{Sc}}$ in prion diseases (Fig. 1). The accumulation of $\mathrm{PrP}^{\mathrm{sc}}$ leads to neuronal death followed by central nervous system (CNS) dysfunction. ${ }^{1)}$ The discovery that mutations in the PrP gene cause inherited prion disease in humans, ${ }^{2)}$ which is transmissible to laboratory animals, ${ }^{3)}$ and the generation of infectious prions in transgenic $(\mathrm{Tg})$ mice expressing mutant PrP assert that prions are devoid of nucleic acid. ${ }^{4,5)}$ It is be also important to mention that we identified a 55-residue peptide of a mutant prion protein that can be refolded into at least two distinct conformations. ${ }^{6}$ ) When inoculated intracere-

\footnotetext{
*To whom correspondence should be addressed: Department of Cortical Function Disorders, National Institute of Neuroscience, National Center of Neurology and Psychiatry, 4-1-1 Ogawahigashi, Kodaira, Tokyo 187-8502, Japan. Tel.: +81-42346-1718; Fax: +81-42-346-1748; E-mail: kaneko@ncnp.go.jp
}

brally into the appropriate transgenic mouse host, 20 of 20 mice receiving the $\beta$-form of this peptide developed signs of CNS dysfunction at $\sim 360$ days, with neurohistologic changes that are pathognomonic of Gerstmann-Sträussler-Scheinker (GSS) disease. ${ }^{7)}$ By contrast, 8 of 8 mice receiving a non$\beta$-form of the peptide failed to develop any neuropathologic changes more than 600 days after the peptide injections. Thus, a chemically synthesized peptide refolded into the appropriate conformation can accelerate or possibly initiate prion disease.

That the cellular isoform of $\mathrm{PrP}^{\mathrm{C}}$ interacts with $\mathrm{PrP}^{\mathrm{Sc}}$ during the formation of nascent $\mathrm{PrP}^{\mathrm{Sc}}$ was surmised from Tg mouse studies where mice expressing a Syrian hamster (SHa) PrP transgene were susceptible to SHa prions. ${ }^{8)}$ When similar Tg mice were produced expressing human $(\mathrm{Hu}) \mathrm{PrP}$, no transmission of $\mathrm{Hu}$ prions was found. However, mice expressing a chimeric Hu-mouse $\mathrm{PrP}$ (Hu-MoPrP) transgene denoted $\mathrm{MHu} 2 \mathrm{M}$ were susceptible to $\mathrm{Hu}$ prions. In addition, we found that $\mathrm{Tg}$ mice expressing HuPrP did become susceptible to Hu prions when they were crossed with PrP-deficient $\left(\operatorname{Prnp}^{0 / 0}\right)$ mice. Studies on the transmission of $\mathrm{Hu}$ prions to $\mathrm{Tg}$ mice 
suggested that another molecule provisionally designated protein $\mathrm{X}$ participates in the formation of nascent $\mathrm{PrP}^{\mathrm{Sc}}{ }^{3)}$ (Fig. 2). We report the identification of the site at which protein $\mathrm{X}$ binds to $\mathrm{PrP}^{\mathrm{C}}$ using scrapie-infected Mo neuroblastoma cells transfected with chimeric Hu-MoPrP genes even though protein $\mathrm{X}$ has not yet been isolated. Substitution of a $\mathrm{Hu}$ residue at position 214 or 218 prevented $\mathrm{PrP}^{\mathrm{Sc}}$ formation. ${ }^{9)}$ The side chains of these residues protrude from the same surface of the C-terminal $\alpha$-helix and form a discontinuous epitope with residues

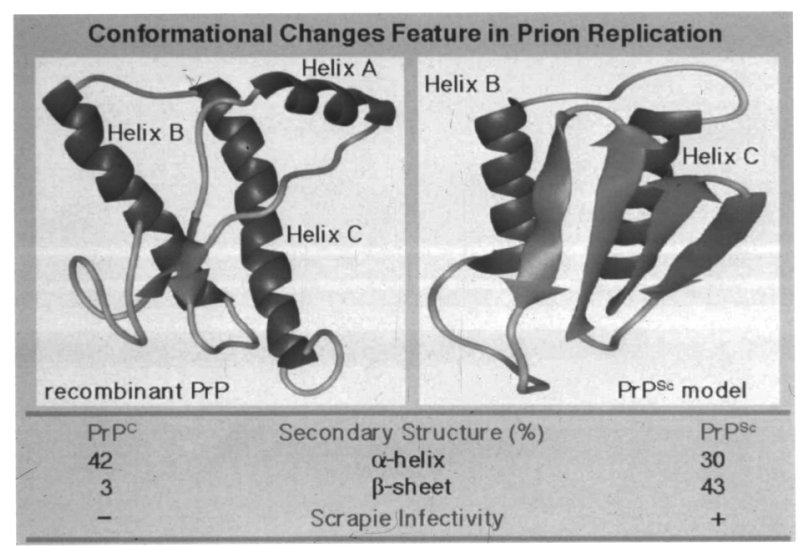

Fig. 1. Two Isoforms of $\operatorname{PrP}$

$\mathrm{PrP}^{\mathrm{C}}$ represents normal cellular isoform of $\mathrm{PrP}$, and $\mathrm{PrP}^{\mathrm{Sc}}$ represents abnormal disease isoform of PrP.
167 and 171 in an adjacent loop (Fig. 3).

\section{Therapeutic Approaches in Prion Disease}

At present, there is no accepted therapy for prion diseases, and whether the drug quinacrine will prove to be effective in treating these diseases remains to be established. ${ }^{10)}$ In addition to quinacrine, ${ }^{11)}$ other compounds that block prion replication as well as stimulate the clearance of existing prions include branched polyamines, ${ }^{12)}$ phthalocyanines and porphyrin derivatives, ${ }^{13)}$ Congo red ${ }^{14)}$ compound $60,{ }^{15}$ ) $\beta$-breaker peptides, ${ }^{16)}$ and anti-PrP antibodies. ${ }^{17,18)}$ Although many of the foregoing compounds are able to clear prions in scrapie-infected neuroblastoma cells, none have been shown to be effective in animals or humans to date. It is noteworthy that both vaccination and passive immunization have effectively decreased $\mathrm{A} \beta$ amyloid deposits in the brains of $\mathrm{Tg}$ mice expressing mutant amyloid precursor protein. Unfortunately, some attempts to vaccinate humans with $\mathrm{A} \beta$ have resulted in allergic meningoencephalitis, which halted the clinical trial. ${ }^{19)}$

\section{Dominant Negative PrP}

One compound was designed to mimic dominant negative inhibition of prion replication. ${ }^{15)}$ Dominant-negative inhibition occurs when the product of the mutant or variant allele interferes with a func-

\section{Heterodimer model}
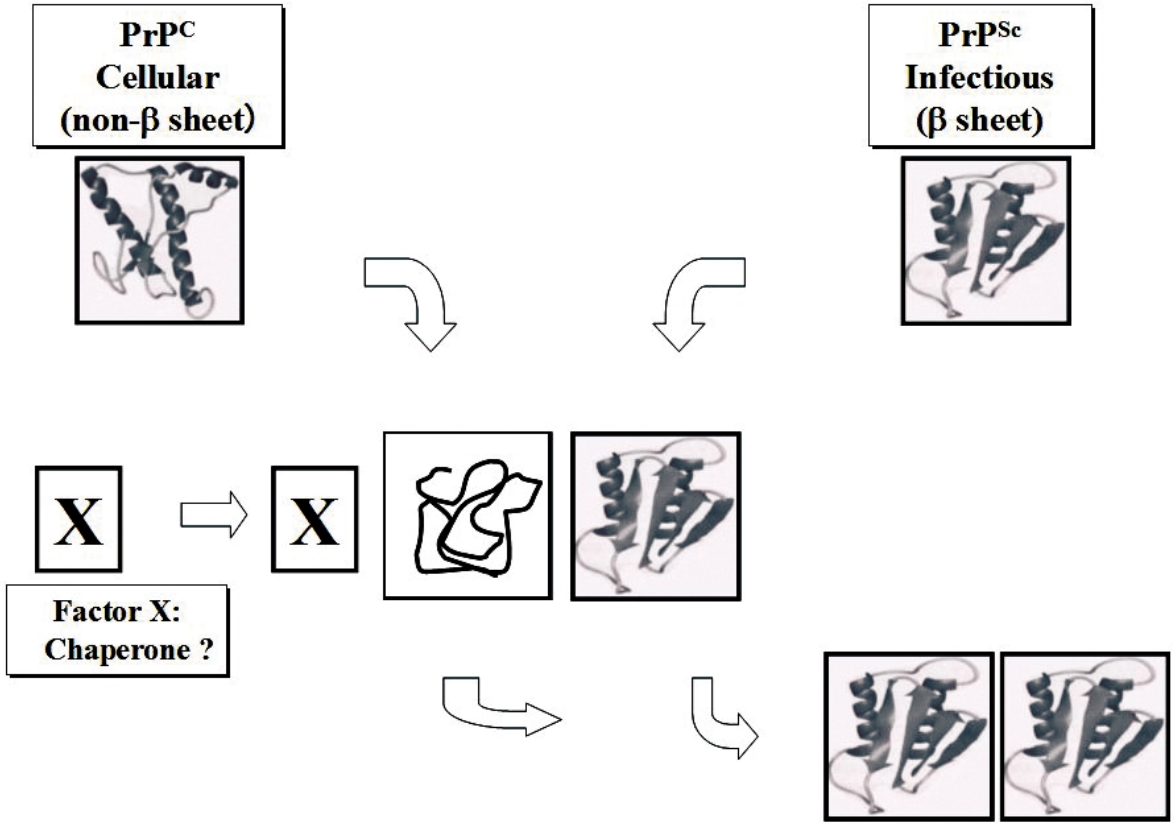

Fig. 2. Heterodimer Model of $\operatorname{PrP}^{\mathrm{Sc}}$ Replication 


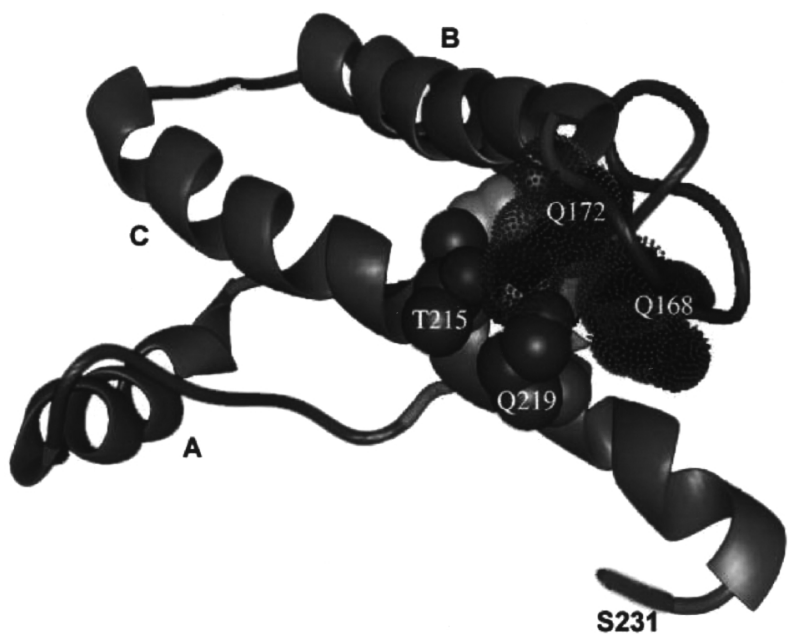

Fig. 3. Hypothetical Molecular Chaperone (Protein X) Binding Site on $\operatorname{PrP}^{\mathrm{C}}$

tion of the wild-type (wt) allelic protein. Naturally occurring polymorphic variants of PrP, and Q171R and $\mathrm{E} 219 \mathrm{~K}$, which are known to render sheep and humans resistant to scrapie and CJD, ${ }^{20,21)}$ were found to act as dominant negatives in scrapie-infected neuroblastoma cells ${ }^{9,22)}$ (Fig. 4).

Based on these findings, we undertook studies on dominant negative PrP. To determine whether dominant-negative inhibition occurs in vivo, we produced Tg mice expressing PrP with either the Q167R or Q218K mutation alone or in combination with wt $\operatorname{PrP}^{23)} \mathrm{Tg}(\mathrm{MoPrP}, \mathrm{Q} 167 \mathrm{R})$ Prnp $^{0 / 0}$ mice expressing mutant $\operatorname{PrP}$ at levels equal to non- $\mathrm{Tg}$ mice remained healthy for $>550$ days, indicating that inoculation with prions did not cause disease. Immunoblots of brain homogenates and histological analysis did not reveal abnormalities. $\mathrm{Tg}(\mathrm{MoPrP}, \mathrm{Q} 167 \mathrm{R}) \mathrm{Prnp}^{+/+}$ mice expressing both mutant and wt PrP did not exhibit neurological dysfunction, but their brains revealed low levels of $\mathrm{PrP}^{\mathrm{Sc}}$, and sections showed numerous vacuoles and severe astrocytic gliosis at 300 days after inoculation. Both $\mathrm{Tg}(\mathrm{MoPrP}$, Q218K)Prnp ${ }^{0 / 0}$ and $\mathrm{Tg}(\mathrm{MoPrP}, \mathrm{Q} 218 \mathrm{~K})$ Prnp $^{+/+}$mice expressing high levels of the transgene product remained healthy for $>300$ days after inoculation. Neither $\mathrm{PrP}^{\mathrm{Sc}}$ nor neuropathologic changes were found.

The inability of $\operatorname{MoPrP}(\mathrm{Q} 167 \mathrm{R})$ and $\operatorname{MoPrP}(\mathrm{Q} 218 \mathrm{~K})$ to support prion replication raises the possibility of producing prion-resistant animals that express PrP with a single amino acid substitution. Because sheep homozygous for $\mathrm{R}$ at position 171 already exist, breeding populations of resistant

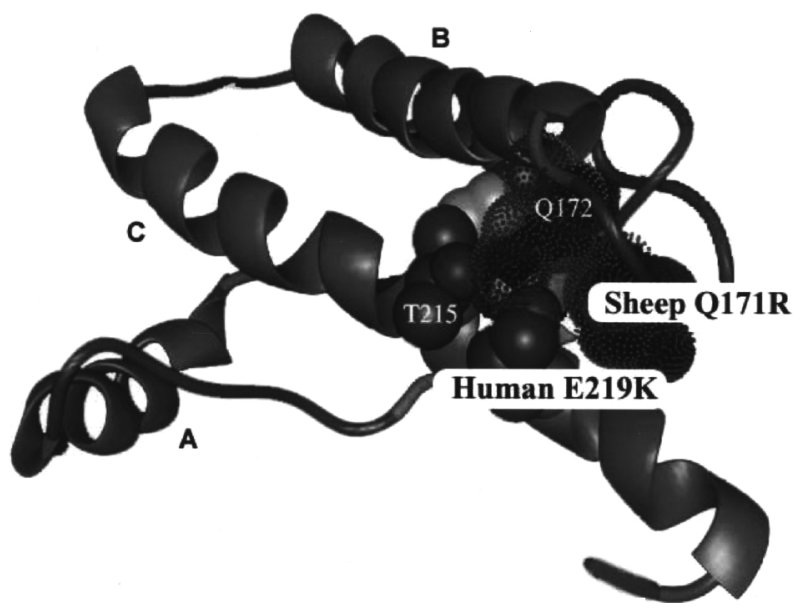

Fig. 4. Two Sheep and Human Polymorphisms Resistant to $\mathrm{PrP}^{\mathrm{Sc}}$ by Exhibiting a Dominant Negative Effect

sheep is a reasonable approach. Presumably, this was the genetic basis of Parry's scrapie eradication program in Great Britain 40 years ago. $\left.{ }^{24}\right)$ A similar approach, inoculating $\operatorname{Tg}(\mathrm{BoPrP}, \mathrm{Q} 179 \mathrm{R})$ or $\mathrm{Tg}(\mathrm{BoPrP}, \mathrm{Q} 230 \mathrm{~K})$ mice with bovine prions might be useful in evaluating the utility of producing prionresistant cattle. Although the introduction of a point mutation may not produce complete resistance to prion infection as disruption of the Prnp gene does, ${ }^{25,26)}$ it may prove to be more desirable to utilize such amino acid substitutions since they are natural polymorphisms in humans and sheep.

\section{Anti-PrP Antibodies}

Reagents specifically binding either PrP conformer may interrupt prion production by inhibiting this interaction. We examined the ability of several recombinant antibody antigen-binding fragments (Fabs) to inhibit prion propagation in cultured mouse neuroblastoma cells $(\mathrm{ScN} 2 \mathrm{a})$ infected with $\mathrm{PrP}^{\mathrm{Sc}}$. We showed that antibodies binding cell-surface $\operatorname{PrP}^{\mathrm{C}}$ inhibit $\mathrm{PrP}^{\mathrm{Sc}}$ formation in a dose-dependent manner ${ }^{17}$ (Fig. 5). In cells treated with the most potent antibody, Fab D18, prion replication is abolished and pre-existing $\mathrm{PrP}^{\mathrm{Sc}}$ is rapidly cleared, suggesting that this antibody may cure an established infection. The potent activity of Fab D18 is associated with its ability to better recognize the total population of $\mathrm{PrP}^{\mathrm{C}}$ molecules on the cell surface, and with the location of its epitope on $\operatorname{PrP}^{\mathrm{C}}$. Our observations support the use of antibodies in the prevention and treatment of prion diseases and identify a region of $\mathrm{PrP}^{\mathrm{C}}$ for drug targeting. 
For in vivo applications, Fab fragments have the disadvantage of a short half-life, and may not efficiently traverse from the peripheral circulation into the central nervous system. Whole-antibody molecules prepared from the Fabs will probably be more useful, but may require engineering to prevent the recruitment of an immunological effect to antibodycoated cells. ${ }^{27)}$

\section{PrPsc Unfolding Biomolecules}

Polypeptide chains are synthesized inside cells as linear molecules and then must be folded into functional structures to perform catalysis. The failure of polypeptides to adopt their proper structure is a major threat to cell function and viability. Therefore, chaperones like HSP70s family proteins that are located in every cellular compartment, bind a wide range of proteins, and play an essential role in

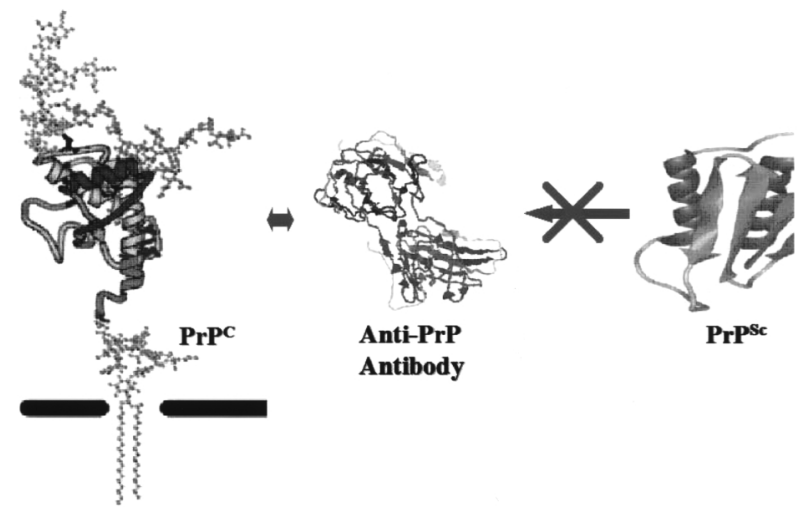

Fig. 5. Inhibition of the $\operatorname{PrP}^{\mathrm{C}}-\operatorname{PrP}^{\mathrm{Sc}}$ Interaction by Anti-PrP Antibody protein folding machinery or preventing misfolding and aggregation of newly synthesized or unfolded proteins. Recently we found and isolated novel protein unfolding activity in S. cerevisiae (N.S.H. paper in preparation). This activity is ATP-dependent and moreover does not have any specificity in vitro. Interestingly, the activity unfolded the prion protein structure even though it included a $\beta$-sheet structure, $\alpha$-synulein, and amloid $\beta$-peptide (1-42) (Fig. 6). By adding specificity to the activity, it may become a powerful tool as a novel therapeutic approach for aggregation diseases by dissolving such aggregates.

We have also explored chaperone activities related to the conformational transition of $\operatorname{PrP}^{\mathrm{C}}$ into $\mathrm{PrP}^{\mathrm{Sc}}$ in mammalian cells. We have attempted to identify activities which modulate the conformation of $\mathrm{PrP}^{\mathrm{C}}$ in mouse neuroblastoma cells using a trypsinsensitivity assay by which we identified the yeast protein unfolding activity as mentioned above. As a result, we obtained activities which modulated recombinant PrP conformation in nuclear, microsome, and cytosol fractions.

\section{New Therapeutic Approach in Neuro- degenerative Disorders}

As it has been shown in past therapeutics approaches for other major human diseases such as cancer or HIV infection, a combination therapy will also be considered for neurodegenerative disorders in the near future. Even if each therapeutic approach exhibits a limited cure with considerable adverse effects, a combination of two or three approaches might be able to improve the patient's prognosis.

\section{A Novel Protein Unfolding Chaperone}

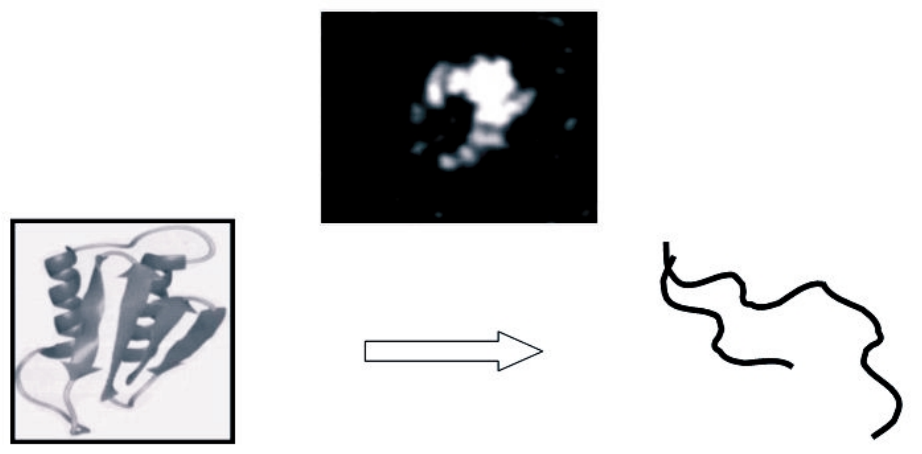

Fig. 6. A Novel Unfolding Chaperone Might Inactivate PrP ${ }^{\mathrm{Sc}}$ 
Whether the combination of drugs and biomolecules such as low-dose quinacrine, dominant negative PrP, anti-PrP antibody, and a $\mathrm{PrP}^{\mathrm{Sc}}$-unfolding chaperone more efficiently inhibits prion replication remains to be established. Such studies are currently underway.

Acknowledgements We thank Dr. Stanley B. Prusiner and his co-workers at the Institute for Neurodegenerative Diseases, the University of California, San Francisco and the Department of Immunology, Scripps Institute of Technology for their supports. This work was supported by grants-in-aids from the Ministry of Health, Labor and Welfare, the Ministry of Education and Science, and Core Research for Evolutional Science and Technology (CREST) of Japan Science and Technology Corporation.

\section{REFERENCES}

1) DeArmond, S. J., Mobley, W. C., DeMott, D. L., Barry, R. A., Beckstead, J. H. and Prusiner, S. B. (1987) Changes in the localization of brain prion proteins during scrapie infection. Neurology, 37, 1271-1280.

2) Hsiao, K., Baker, H. F., Crow, T. J., Poulter, M., Owen, F., Terwilliger, J. D., Westaway, D., Ott, J. and Prusiner, S. B. (1989) Linkage of a prion protein missense variant to Gerstmann-Strossler syndrome. Nature (London), 338, 342-345.

3) Telling, G. C., Scott, M., Mastrianni, J., Gabizon, R., Torchia, M., Cohen, F. E., DeArmond, S. J. and Prusiner, S. B. (1995) Prion propagation in mice expressing human and chimeric PrP transgenes implicates the interaction of cellular PrP with another protein. Cell, 83, 79-90.

4) Hsiao, K. K., Scott, M., Foster, D., Groth, D. F., DeArmond, S. J. and Prusiner, S. B. (1990) Spontaneous neurodegeneration in transgenic mice with mutant prion protein. Science, 250, 1587-1590.

5) Telling, G. C., Haga, T., Torchia, M., Tremblay, P., DeArmond, S. J. and Prusiner, S. B. (1996) Interactions between wild-type and mutant prion proteins modulate neurodegeneration in transgenic mice. Genes Dev., 10, 1736-1750.

6) Kaneko, K., Wille, H., Mehlhorn, I., Zhang, H., Ball, H., Cohen, F. E., Baldwin, M. A. and Prusiner, S. B. (1997) Molecular properties of complexes formed between the prion protein and synthetic peptides. $J$. Mol. Biol., 270, 574-586.

7) Kaneko, K., Ball, H. L., Wille, H., Zhang, H., Groth,
D., Torchia, M., Tremblay, P., Safar, J., Prusiner, S. B., DeArmond, S. J., Baldwin, M. A. and Cohen, F. E. (2000) A synthetic peptide initiates GerstmannStraussler-Scheinker (GSS) Disease in transgenic mice. Running title: A peptide causes GerstmannStraussler-Scheinker disease. J. Mol. Biol., 295, $997-$ 1007.

8) Prusiner, S. B., Scott, M., Foster, D., Pan, K.-M., Groth, D., Mirenda, C., Torchia, M., Yang, S.-L., Serban, D., Carlson, G. A., Hoppe, P. C., Westaway, D. and DeArmond, S. J. (1990) Transgenetic studies implicate interactions between homologous PrP isoforms in scrapie prion replication. Cell, $\mathbf{6 3}, 673-$ 686.

9) Kaneko, K., Zulianello, L., Scott, M., Cooper, C. M., Wallace, A. C., James, T. L., Cohen, F. E. and Prusiner, S. B. (1997) Evidence for protein X binding to a discontinuous epitope on the cellular prion protein during scrapie prion propagation. Proc. Natl. Acad. Sci. U.S.A., 94, 10069-10074.

10) Korth, C., May, B. C. H., Cohen, F. E. and Prusiner, S. B. (2001) Acridine and phenothiazine derivatives as pharmacotherapeutics for prion disease. Proc. Natl. Acad. Sci. U.S.A., 98, 9836-9841.

11) Doh-Ura, K., Iwaki, T. and Caughey, B. (2000) Lysosomotropic agents and cysteine protease inhibitors inhibit scrapie- associated prion protein accumulation. J. Virol., 74, 4894-4897.

12) Supattapone, S., Nguyen, H. O., Cohen, F. E., Prusiner, S. B. and Scott, M. R. (1999) Elimination of prions by branched polyamines and implications for therapeutics. Proc. Natl. Acad. Sci. U.S.A., 96, 14529-14534.

13) Caughey, W. S., Raymond, L. D., Horiuchi, M. and Caughey, B. (1998) Inhibition of protease-resistant prion protein formation by porphyrins and phthalocyanines. Proc. Natl. Acad. Sci. U.S.A., 95, 12117-12122.

14) Demaimay, R., Harper, J., Gordon, H., Weaver, D., Chesebro, B. and Caughey, B. (1998) Structural aspects of Congo red as an inhibitor of proteaseresistant prion protein formation. J. Neurochem., 71, 2534-2541.

15) Perrier, V., Wallace, A., Kaneko, K., Safar, J., Prusiner, S. B. and Cohen, F. E. (2000) Mimicking dominant negative inhibition of prion replication through structure-based drug design. Proc. Natl. Acad. Sci. U.S.A., 97, 6073-6078.

16) Soto, C., Kascsak, R. J., Saborio, G. P., Aucouturier, P., Wisniewski, T., Prelli, F., Kascsak, R., Mendez, E., Harris, D. A., Ironside, J., Tagliavini, F., Carp, R. I. and Frangione, B. (2000) Reversion of prion protein conformational changes by synthetic betasheet breaker peptides. Lancet, 355, 192-197. 
17) Peretz, D., Williamson, R. A., Kaneko, K., Vergara, J., Leclerc, E., Schmitt-Ulms, G., Mehlhorn, I. R., Legname, G., Wormald, M. R., Rudd, P. M., Dwek, R. A., Burton, D. R. and Prusiner, S. B. (2001) Antibodies inhibit prion propagation and clear cell cultures of prion infectivity. Nature (London), 412, 739-743.

18) Enari, M., Flechsig, E. and Weissmann, C. (2001) Scrapie prion protein accumulation by scrapieinfected neuroblastoma cells abrogated by exposure to a prion protein antibody. Proc. Natl. Acad. Sci. U.S.A., 98, 9295-9299.

19) Birmingham, K. and Frantz, S. (2002) Setback to Alzheimer vaccine studies. Nat. Med., 8, 199-200.

20) Westaway, D., Zuliani, V., Cooper, C. M., Da Costa, M., Neuman, S., Jenny, A. L., Detwiler, L. and Prusiner, S. B. (1994) Homozygosity for prion protein alleles encoding glutamine-171 renders sheep susceptible to natural scrapie. Genes Dev., 8 , 959-969.

21) Shibuya, S., Higuchi, J., Shin, R. W., Tateishi, J. and Kitamoto, T. (1998) Protective prion protein polymorphisms against sporadic Creutzfeldt-Jakob disease [letter]. Lancet, 351, 419.

22) Zulianello, L., Kaneko, K., Scott, M., Erpel, S., Han,
D., Cohen, F. E. and Prusiner, S. B. (2000) Dominant-negative inhibition of prion formation diminished by deletion mutagenesis of the prion protein. J. Virol., 74, 4351-4360.

23) Perrier, V., Kaneko, K., Safar, J., Vergara, J., Tremblay, P., DeArmond, S. J., Cohen, F. E., Prusiner, S. B. and Wallace, A. C. (2002) Dominantnegative inhibition of prion replication in transgenic mice. Proc. Natl. Acad. Sci. U.S.A., 99, 1307913084.

24) Parry, H. B. (1962) Scrapie: a transmissible and hereditary disease of sheep. Heredity, 17, 75-105.

25) Bueler, H., Aguzzi, A., Sailer, A., Greiner, R.-A., Autenried, P., Aguet, M. and Weissmann, C. (1993) Mice devoid of PrP are resistant to scrapie. Cell, 73, 1339-1347.

26) Prusiner, S. B., Groth, D., Serban, A., Stahl, N. and Gabizon, R. (1993) Attempts to restore scrapie prion infectivity after exposure to protein denaturants. Proc. Natl. Acad. Sci. U.S.A., 90, 2793-2797.

27) Idusogie, E. E., Presta, L. G., Gazzano-Santoro, H., Totpal, K., Wong, P. Y., Ultsch, M., Meng, Y. G. and Mulkerrin, M. G. (2000) Mapping of the C1q binding site on rituxan, a chimeric antibody with a human IgG1 Fc. J. Immunol., 164, 4178-4184. 